I. Yakhno ${ }^{1}$, O. Malyk ${ }^{1}$, S. Hatsenko ${ }^{2}$, A. Shyshatskyi ${ }^{3}$

${ }^{1}$ Main Headquarters of the National Guard of Ukraine, Kyiv, Ukraine,

${ }^{2}$ National Defence University of Ukraine named after Ivan Chernyakhovsky, Kyiv, Ukraine

${ }^{3}$ Central Research Institute of Weapons and Military Equipment of Armed Forces of Ukraine, Kyiv

\title{
FOUNDATION OF THE FACTORS AFFECTING THE PLANNING AND MANAGEMENT OF THE RADIOELECTRONIC DEVELOPMENT
}

\begin{abstract}
The military-political situation around Ukraine is characterized by high dynamism and instability of events and processes. Against the background of the main task of the Armed Forces of Ukraine at the present stage of development is the intensification of intelligence in order to timely prevent the top leadership of Ukraine about possible armed aggression of the Russian Federation, bringing its troops (forces) to higher levels of combat readiness and preventing the active actions of illegal armed groups. Providing information superiority over the enemy today is becoming a prerequisite for conducting military operations. The main type of information support is military intelligence, and its basis is radio-electronic intelligence. The authors of the above-mentioned research carried out an analysis of the influence of external and internal factors influencing the efficiency of conducting radio-electronic intelligence. During the research, the authors used the basic provisions of the theory of radio-electronic intelligence, the theory of communication, the theory of electronic warfare, the theory of signals, and general scientific methods of analysis and synthesis. According to the results of the research, it can be concluded that the effectiveness of conducting radio-electronic intelligence is influenced by the state and level of combat training and combat readiness of the personnel of the radio-intelligence group; operational and technical capabilities of electronic intelligence tools and communication of the forces; the need to move a forces of radio-electronic intelligence; fire influence of the enemy; restrictions that take into account the influence of electronic warfare devices; natural, meteorological, geographical conditions, and so on. The influence of these factors leads to an incomplete realization of the objective capabilities of the forces of radio-electronic intelligence, and in a number of cases, to their significant decrease. Taking into account the above, the direction of further research should be considered the development of a scientific and methodical apparatus for improving the efficiency of conducting radio-electronic intelligence by the forces of radio-electronic intelligence.
\end{abstract}

Keywords: radio communication systems, radio resources, noise immunity, radio-electronic suppression, radioelectronic intelligence, secrecy.

\section{Introduction}

The military-political situation around Ukraine is characterized by high dynamism and instability of events and processes [1-3].

The main task of the Armed Forces of Ukraine (AF of Ukraine) at the present stage is to intensify intelligence in order to timely prevent the top management of Ukraine about possible armed aggression of the Russian Federation (RF), to bring its troops (forces) to higher levels of combat readiness, to prevent active actions of illegal armed units [2].

Proceeding from the fact that the achievement of the information superiority over the enemy today becomes the main condition for the successful conduct of operations, combat operations, battles, military intelligence, as the main type of information support for troops (forces), gaining qualitatively new importance, with the radio-electronic intelligence (REI) as a component of military intelligence, up to $90 \%$ of intelligence objects are exposed, because of the work of radio-electronic devices (RED) of scattered objects $[4,5]$.

Creation of a modern intelligence system is carried out by reforming parts and units of the radio-electronic intelligence, optimization of their organizational and staff structure.

This requires:

improvement of the REI process of conducting intelligence, collecting, processing, analyzing and accumulating it; development of new and upgrading existing REI facilities, which are armed with parts and units of the REI;

improvement of the combat training of parts and units of the REI, especially those related to the practical implementation of the personnel of their assigned functional duties.

One of the new approaches can be seen in the practice of a wider and more flexible application of REI groups.

The purpose of this article is to justify the factors that influence the planning and conduct of radioelectronic intelligence.

\section{Presentation of the main material}

The essence of the planning of radio-electronic intelligence is to elaborate on a detailed elaboration of all issues related to the combat use of radio-electronic intelligence forces and devices, and to develop measures for their effective combat use in order to ensure disclosure:

- changes in operational and radio electronic environment;

- signs of direct preparation for the resolution of war (the beginning of military action) or a change in their form (excluding the suddenness of the enemy's actions);

- intelligence data necessary for solving the tasks.

Consider the factors that affect the overall effectiveness of planning and conducting radio- 
electronic intelligence. They conditionally can be divided into external and internal.

External factors include:

- composition, character, forms and methods of using the Armed Forces;

- active development of control systems of troops and armaments of the armed forces of the expatriate states measures to restrict the information space;

- radio-masking and secret control of troops.

Among the internal factors distinguish:

- the effectiveness of organization and conduction of intelligence;

- structure, capabilities of forces and intelligence (degree of technical equipment of extractive units);

- efficiency and flexibility of the management system of the extractive departments;

- staffing and level of preparation of mining and information-analytical subdivisions;

- ways of extraction and processing of intelligence information;

- level of automation of control points (CP) and extraction posts;

- the combat order of parts of the REI and the possibility of its rapid change, depending on the situation;

- organization of comprehensive support.

Composition, nature, forms and methods of using armed forces

In modern conditions, armed struggle covers the application of the all virtually spheres of human life. Scientific and technological progress undoubtedly extends in the military sphere, which, accordingly, affects contemporary views on the operational and combat use of the armed forces. [5-8].

Developed in the leading countries of the world

In the armed forces of the leading powers of the world, a unified global network-centered system is created to unite armies dispersed in a JWS (Joint Warfighting Space) and provides horizontal and vertical integration of forces and devices.

Leading military experts identified the main features of the war in the framework of the Net-Centric Warfare concept compared with the usual methods of warfare:

the use of geographically dispersed forces means that there is no need to redeploy forces, devices and personnel to the front line, or in areas close to the object being attacked or defending;

the forces participating in the centrifugal wars are highly intellectual, which means the possibility of their self-synchronization, autonomous functioning, independent decision-making on the use of the devices of defeat and the operational retargeting of the devices of damage in accordance with the changes in the combat situation;

providing stable communication channels between component elements of Net-Centric Warfare.

Conceptual generalized structure of the process of conducting a network-centric war is presented in fig. $1[3]$.
Development of communication systems and control of troops and weapons of the armed forces of the scattered states.

Providing information superiority over enemy control systems, improving the quality of providing information and telecommunication services to the authorities is considered as one of the priority areas for increasing the combat capabilities of troops.

The analysis of the construction of communication systems of operational, operational and strategic parts of the management of Israel, Austria, Finland, Sweden shows that their common integration with the communication networks of civilian operators, the high level of branching and technical equipment of the stationary systems of military contacts' bunch

The military leadership of the Russian Federation (RF) as the main ways to improve communication systems sees the complex development of territorial communications systems (TCS) of the regions, construction of communication systems of general use (CSGU) associations that integrate all types of information exchange, automatic switching of channels and messages and secrecy of them with guaranteed stability. The main component of the CSGU will be the reference (transit) communication network, the high structural survivability of which will be achieved by providing the necessary density of the spatial coverage of the band of operational construction of the association troops.

In this way, the characteristic features of the development of communication and information systems of the armed forces of the leading countries today are as follows [9]:

- the application of the same architectural principles of network construction for all levels of the management system;

- application of the unified technical devices of communication and automation and standards at all levels (providing interoperability);

- provision of typical telecommunication services at all levels of the communication system: language, data (IP data), video (from low to high speed);

- the possibility of creating operational (situational) networks depending on the tasks set;

- creation of interconnected automated control systems capable of functioning in a single information space;

- widespread use of civil standards, protocols and technical solutions;

- observance of uniform (for NATO) standards, agreements and recommendations;

- ensuring the full integration of military and civilian systems and communication facilities;

- the use of communication lines leased to civilian agencies of NATO member countries.

Based on the analysis of the use of frequency bands for military communication systems, it should be noted that satellite communication systems (SCS) play an important role in ensuring reliable management of the Armed Forces both on the territory of the state and abroad. 


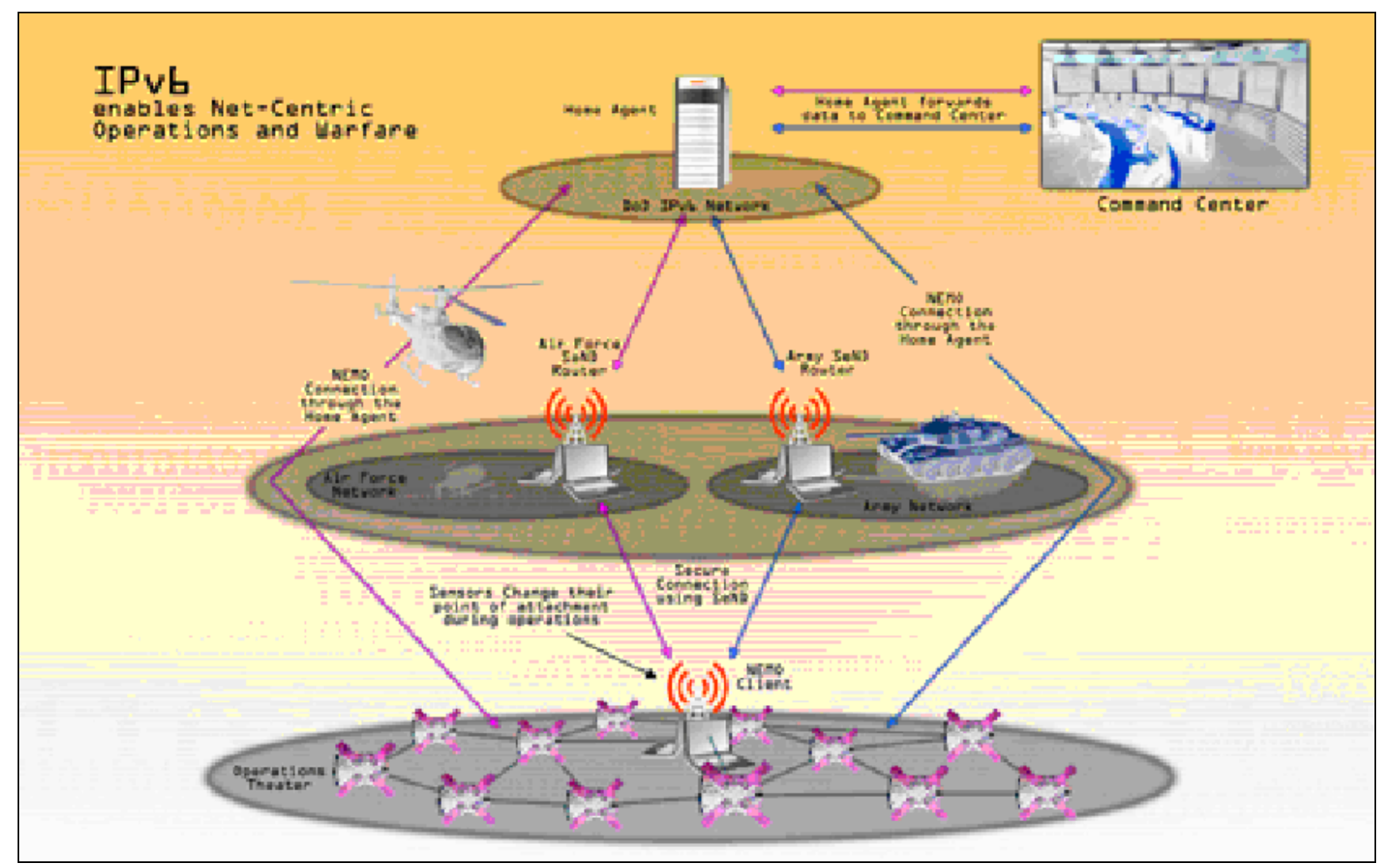

Fig. 1. Conceptual generalized structure of the process of conducting a network-centric war

In addition to the rental of channels for commercial aircrafts, the US Armed Forces (USA Army, United Kingdom, Britain, France, Italy, etc.) has developed, improved and developed new specialized Airborne Forces: NATO, DSCS, Flitsatcom, Afsatcom, Milstar, UFO, WGS, TSAT, MUOS, AEHF and others.

According to USA experts, existing program plans will not be able to meet all the needs of satellite communication channels.

These findings led to the development of a TCA (Transformational Communications Architecture), which should take effect no earlier than 2020 .

The new architecture involves the use of several satellite systems for the organization of broadband access to information.

The effectiveness of organization and conduct of intelligence

In the context of the continuous development of the control systems of troops and weapons, intelligencesearch activities are acquiring of paramount importance for the military part of the electronic intelligence.

At the same time, the main efforts of reconnaissance search in the SW and USW bands should focus on finding new sources of intelligence and exposing changes in the control and communications systems of the armed forces of the scattered states.

Particular attention should be paid to the implementation of all necessary measures to improve the search for informative channels of satellite communications, which are leased to ensure the functioning of state and military intelligence agencies.

In order to ensure the qualitative performance of reconnaissance search tasks, constant and clear search guidance, planning of conducting search activities at the command post of the military part of the REI, a schedule of reconnaissance-search work and a model of reconnaissance-search work for the current year is developed.

During the operational and technical analysis of radio waves, there is a search for ways of providing hardware and information access to new sources of intelligence using sophisticated types of radio signals, developing recommendations for intercepting new sources of intelligence information of the observed, developing requirements for the necessary technical equipment with the devices of REI and methodical support for their application.

Improvement of the efficiency of the technical analysis units can be ensured due to their first-time equipment with the latest technical equipment of the REI, staffing by the most experienced specialists.

In order to ensure the effective implementation of the tasks of the flying service in the military part, it is necessary to carry out a complex of measures, which includes preparation of the allocated forces and devices for application, organization of high-quality and continuous work in the radio-langator network and hardware and software tools, carrying out with the established frequency of coverage of the antennafeeder systems of all radio-detectors with control hubs, implementation of measures to increase the level of special training of personnel of flying sub-units and units of the radiotechnical intelligence, training of downlink operators and testing of tactical and technical characteristics of radio bearings by the devices of conducting in the radiolabeled network 
networks a control over the radiation sources with known geographic coordinates, providing high-quality processing of the results of the glide by subsequent changes in command posts and officers responsible for the belting service, control and evaluation of the best service with summarizing the work and bringing it to the units involved in the tasks direction-finding service.

Structure, capabilities of forces and the devices of reconnaissance (degree of technical equipment of extractive units)

At the present stage of development of science and technology, radio-intelligence devices are most appropriate to be implemented on the basis of automated information extraction complexes (AIEC), which should combine the best modern achievements of microelectronics and software.

Efficiency and flexibility of the management system of extraction units

Successful execution of reconnaissance tasks in the course of REI conducting, including depends on well-thought-out, clearly organized and reliably functioning management and communication system.

It should provide a clear organization of processes for extracting and processing intelligence information, a report of the command data obtained, continuous interaction by the forces and devices.

Complexity and level of preparation of mining and information-analytical subdivisions

The quality of intelligence tasks depends on the training of the personnel involved in the extraction, processing and analysis of the results of the electronic intelligence.

Extractive units, technical analysis units, command post must be staffed with officers whose level of training provides for the fulfillment of combat missions in planning, organizing and conducting radio-electronic intelligence, timely extraction and prompt and correct processing of intelligence information, timely reporting of intelligence received to the command.

In addition to professional training as a radio engineer, a clear knowledge of system engineering, informatization, knowledge of a foreign language (first of all, command post officers) is required. In the current conditions, without knowledge of foreign languages, it is not possible to carry out qualitative tasks and engage with NATO Armed Forces.

Methods of extracting and processing intelligence information

The main ways of obtaining intelligence information in the REI is to receive radio frequencies and to determine the location of the electronic equipment of the armed forces of the scattered states. Radio interference interception includes [8]:

the detection of emitting radio-electronic devices in the frequency range and in space;

reception of detected radio emission;

signal analysis;

transfer of intelligence received for further processing.

The processing of intelligence information is carried out in order to transform certain detached intelligence information into intelligence summaries that reveal the content of the issues identified as intelligence tasks.

During processing the following main tasks are solved:

- disclosure of the radio electronic situation in the intelligence band;

- identification of intelligence features that characterize the composition, state of combat readiness, organization, the character of activities and intentions of the Armed Forces of the scattered states;

- disclosure of intelligence objects based on technical recognition data, as well as their location, the purpose of the identified sources;

- clarification (confirmation) of the location of the sources (objects) of the REI on the basis of data acquisition, the results of the analysis of intercepted messages and other data;

- assessment of tactical and technical characteristics, composition, organization of the RED use and control systems and the provision of troops (forces) that are being deployed;

- identification of specific features (signs) of radiation;

- development of primary data for situational control of the forces and devices of the REI.

In order to increase the efficiency of the processes of extraction and processing of intelligence information, it is necessary to provide an automated collection of the results of interception and to implement a high-speed closed wire (computer) communication with peripheral and interacting parts, as well as with higher command post, which will allow collecting, processing of radio interception materials (results measuring parameters of RTD) and providing them with information to consumers in real time, to create a unified centralized database on communication systems, devices the RTD of the armed forces of the scattered states, to provide access to it to users who fill this base and use it to make a decision.

Automation level of the control points and extraction posts

One of the main requirements for intelligence processes is the automation of collecting, processing, storing and transmitting data to consumers.

It consists in the integrated use of modern methods, hardware and software-algorithmic devices of automation in the processes of extraction, collection, processing of intelligence information, control of forces and devices and should provide:

- management of the work of REI forces and devices in search, observation, location, etc;

- registration and processing of the obtained data;

- sorting of intelligence information on persistent signs and characteristics, the formation of databases, their accounting and storage;

- distribution of flows of intelligence received between the command post officers who process them;

- modeling, algorithmization and programming of the processes of the REI conducting; 
- solving informational and settlement tasks related to the organization of REI, management of forces and devices, assessment of the effectiveness of their work;

- the transfer of intelligence information to consumers in real time.

Automation tools have to meet the information security requirements and provide the necessary level of protection against unauthorized access to information programs.

The combat order of parts of the REI and the possibility of its rapid change, depending on the situation.

One of the main factors influencing the efficiency of conducting radio-electronic intelligence is the combat order of the REI part and the possibility of its rapid change, depending on the situation.

In this case, the choice of areas of the location of intelligence tools cannot be made on a template that is suitable for all conditions of the situation. In each individual case, such a choice requires an artistic decision based on the specific circumstances of the situation, set goals for the organization and maintenance of the REI, the nature of the use of the communications and data transmission facilities in the armed forces of the states, the conditions for the distribution of radio waves, and the availability and capabilities. intelligence tools.

The choice of areas for the location of reconnaissance assets must be carried out in such a way as to ensure as far as possible the fulfillment of the requirements for combat orders, the main of which is the reliable identification of working sources, continuous intelligence, best positioning conditions and the maximum accuracy of the location of sources of REI sources, concentration the main exploration efforts on the main directions, the possibility of rapid maneuver by the forces and devices of radio-electronic intelligenc and others.

Organization of comprehensive support.

Ensuring the military activity of the military part of the REI is organized and carried out in order to create favorable conditions for the successful implementation of the set of intelligence tasks in any circumstances of the current situation.

Creation of such conditions is ensured through a series of measures of operational, material and technical, military support, etc.

\section{The conclusions from the article}

In planning and conducting radio-electronic intelligence, a maneuverable group of radio-electronic intelligence from a part of a maneuverable unit (maneuver center or separate center) of the regional center of the REI during the conduct of battlefield intelligence is influenced by both the general factors that are listed earlier and the specific factors that are more common in the performance of intelligence tasks by the maneuverable group of REIs.

Factors that determine the objective capabilities of the RAI maneuverable group. These are factors such as:

the state and level of combat training and combat readiness of the personnel of the REI maneuverable group;

operational and technical capabilities of the facilities and complexes of the REI, the connection of the REI maneuverable group;

the need to move the REI maneuverable group;

fire influence of the enemy;

limitations that take into account the REI influence;

natural, meteorological, geographical conditions, etc.

The influence of these factors leads to $a b$ incomplete realization of the objective capabilities of the REI maneuverable group, and in a number of cases, and to their significant decrease. But, if the organization of electronic intelligence carries out a thorough analysis of all available factors, there is a possibility of impossibility or reduction of their negative impact.

Taking into account the above, the direction of further research should be considered the development of a scientific and methodical apparatus for improving the efficiency of the radio-electronic intelligence conducting by maneuvering groups of radio-electronic intelligence, taking into account various factors.

\section{REFERENCES}

1. Alimpiyev, A.M. and Pevtsov, G.V(2017)." Features of the hybrid war against the Russian Federation. Experience gained by the Air Forces of the Armed Forces of Ukraine", Science and Technology of the Air Forces of the Armed Forces of Ukraine, No. 2(27), pp. 19-25. https://doi.org/10.30748/nitps.2017.27.03.

2. Bogdanovich, V.Yu., Svida, I.Yu. and Syrotenko, A.M(2018). "The concept of the integrated use of military and non-military forces and means to ensure a sufficient level of military security of the state ", Science and Technology of the Air Forces of the Armed Forces of Ukraine, No. 2(31), pp. 16-29. https://doi.org/10.30748/nitps.2018.31.02.

3. Shyshatskiy, A.V., Bashkirov, O.M. and Kostina, O.M (2015). "Development of integrated systems and data for Armed Forces", Arms and military equipment, No 1(5), pp. 35-40. available at: http://journals.uran.ua/index.php/24140651/issue/view/1\%285\%29\%202015 (last accessed november 25, 2018).

4. Hatsenko, S.S(2017). "Methodology for assessing the operational situation in automated control systems of troops under uncertainty", Science and Technology of the Air Forces of the Armed Forces of Ukraine, No. 1(26), pp. 101-105. https://doi.org/10.30748/nitps.2017.26.21.

5. Zhuk, O.G., Shyshatskiy, A.V., Zhuk, P.V. and Zhyvotovskyi, R.M (2017). "Methodological substances of management of the radio-resource managing systems of military radio communication", Information Processing Systems, Vol. 5(151), pp. 16-25. https://doi.org/10.30748/soi.2017.151.02.

6. Kuvshinov, O.V., Shyshatskiy, A.V., Lyutov, V.V and Zhuk, O.G(2017). "Analysis of ways for increasing the secrecy of broadband radiocommunication systems "Scientific works of Kharkiv National University of Air Forces, No. 1(50), pp. 24-28. 
7. Popov, A.O., Tverdokhlibov, V.V(2014). “ General tendencies of development of means of electronic warfare ”, Arms and military equipment, No. 4 (4), pp. 4-10.

8. Serhiienko, V.D., Popov, A.O., Zibin, S.D., Bychkov, A.N., Pidhorodetskyi, M.M (2017). "Analysis of the state of the art of multifunctional electronic warfare means and complexes." Modern Information Technologies In the sphere of security and defence, No.1(28), pp.135-143.

9. Romanenko, I and Shyshatskyi, A (2017). “Analysis of modern condition of military radiocommunication system", Advanced Information Systems, Vol. 1, No. 1, pp. 28-33 DOI: https://doi.org/10.20998/2522-9052.2017.1.05.

Рецензент: д-р техн. наук, проф. Г. В. Худов, Український державний університет залізничного транспорту, Харків Надійшла (received) 22.11.2018 Прийнята до друку (accepted for publication) 23.01.2019

\section{Обгрунтування чинників, які впливають на планування і ведення радіоелектронної розвідки}

І. Ю. Яхно, О. С. Малик, С. С. Гаценко, А. В. Шишацький

Воєнно-політична обстановка навколо України характеризується високою динамічністю і нестабільністю подій та процесів. На фоні зазначеного основним завданням Збройних Сил України на сучасному етапі розбудови $є$ активізація розвідки $з$ метою своєчасного попередження вищого керівництва України про можливу збройну агресію Російської Федерації, приведення у вищі ступені бойової готовності іiї військ (сил), попередження активним діям незаконних збройних формувань. Забезпечення інформаційної переваги над противником на сьогодні стає основною умовою для ведення воєнних операцій. Основним видом інформаційного забезпечення $є$ воєнна розвідка, а іiі основою радіоелектронна розвідка. Авторами зазначеного дослідження було проведено аналіз впливу зовнішніх та внутрішніх факторів що впливають на ефективність ведення радіоелектронної розвідки. В ході дослідження авторами були використані основні положення теорії радіоелектронної розвідки, теорії зв'язку, теорії радіоелектронної боротьби, теорії сигналів та загальнонаукові методи аналізу та синтезу. За результатами проведеного дослідження можна зробити висновки про те, що на ефективність ведення радіоелектронної розвідки впливає: стан та рівень бойової підготовки і бойової готовності особового складу маневреної групи радіоелектронної розвідки; оперативно-технічні можливості засобів і комплексів радіоелектронної розвідки та зв'язку маневреної групи; необхідність переміщення маневреної групи радіоелектронної розвідки; вогневий вплив противника; обмеження, що враховують вплив засобів радіоелектронної боротьби; природні, метеорологічні, географічні умови і та інш. Вплив перерахованих чинників приводить до неповної реалізації об'єктивних можливостей маневреної групи радіоелектронної розвідки, а у ряді випадків і до їх значного зниження. Враховуючи зазначене, напрямком подальших досліджень слід вважати розробку науково-методичного апарату підвищення ефективності ведення радіоелектронної розвідки маневреними групами радіоелектронної розвідки.

Ключові слова: система радіозв’язку, радіоресурс, завадозахищеність, радіелектроннне подавлення, радіоелектронна розвідка, скритність.

\section{Обоснование факторов,}

влияющих на планирование и ведение радиоэлектронной разведки

$$
\text { И. Ю. Яхно, О. С. Малык, С. С. Гаценко, А. В. Шишацкий }
$$

Военно-политическая обстановка вокруг Украины характеризуется высокой динамичностью и нестабильностью событий и процессов. На фоне указанного основной задачей Вооруженных Сил Украины на современном этапе развития является активизация разведки с целью своевременного предупреждения высшего руководства Украины о возможной вооруженной агрессии Российской Федерации, приведение в высшие степени боевой готовности ее войск (сил), предупреждения активных действий незаконных вооруженных формирований. Обеспечение информационного превосходства над противником на сегодня становится основным условием для ведения военных операций. Основным видом информационного обеспечения является военная разведка, а ее основой - радиоэлектронная разведка. Авторами указанного исследования был проведен анализ влияния внешних и внутренних факторов на эффективность ведения радиоэлектронной разведки. В ходе исследования авторами были использованы основные положения теории радиоэлектронной разведки, теории связи, теории радиоэлектронной борьбы, теории сигналов и общенаучные методы анализа и синтеза. По результатам проведенного исследования можно сделать выводы о том, что на эффективность ведения радиоэлектронной разведки влияет: состояние и уровень боевой подготовки и боевой готовности личного состава маневренной группы радиоэлектронной разведки; оперативно-технические возможности средств и комплексов радиоэлектронной разведки и связи маневренной группы; необходимость перемещения маневренной группы радиоэлектронной разведки; огневое воздействие противника; ограничения, учитывающие влияние средств радиоэлектронной борьбы; природные, метеорологические, географические условия и др. Влияние перечисленных факторов приводит к неполной реализации объективных возможностей маневренной группы радиоэлектронной разведки, а в ряде случаев и к их значительному снижению. Учитывая указанное, направлением дальнейших исследований следует считать разработку научно-методического аппарата повышения эффективности ведения радиоэлектронной разведки маневренными группами радиоэлектронной разведки.

Ключевые слова: система радиосвязи, радио ресурс, помехозащищенность, радиоэлектронное подавления, радиоэлектронная разведка, скрытность. 